\title{
Pengujian Nilai Keasaman (pH) Air Tailing PT Freeport Indonesia Pada Mile Pos 39 Sungai Otomona Timika Mimika Papua
}

\author{
Sriyono, Dodid Murdohardono, Suparno \\ PEM Akamigas
}

\begin{abstract}
Abstrak
Dalam proses pengolahan bijih PT. Freeport Indonesia membutuhkan kapur (CaO) sebesar 600 gr/ton bijih dan kapur tersebut akan berpengaruh pada besaran nilai $\mathrm{pH}$ pada tailing yang selanjutnya di alirkan ke sungai Otomona. Upaya untuk menjaga lingkungan di sekitar daerah aliran sungai tailing PT. Freeport Indonesia selalu melakukan uji sampel air dari mile pos 39 yaitu titik stasiun pantau setelah pertemuan antara Sungai Aghawagon dengan sungai pembawa tailing untuk diketahui beberapa parameter kimia yang terkandung di dalamnya adapun hasil pemantauan dalam tahun 2016 untuk nilai Ph berkisar antara 7,70 - 8,30 sedangkan berdasarkan hasil pengujian secara teoritis didapatkan nilai berkisar antara 7,89-8,19 dengan demikian hasil pengujian sampel air sungai oleh PT. Freeport Indonesia dibandingkan dengan perhitungan secara teoritis tidak terdapat perbedaan yang signifikan sedangkan menurut baku mutu tailing yang berlaku nilai ambang batasnya adalah sebesar 6 - 9 maka dengan demikian hasil uji sampel PT. Freeport Indonesia tidak diragukan dan dapat diterima.
\end{abstract}

Kata kunci: Tailing, debit air sungai, Potential of Hidrogen (Ph).

\begin{abstract}
In the processing of ore PT. Freeport Indonesia requires lime (CaO) of $600 \mathrm{gr} /$ ton of ore and the lime will affect the amount of $\mathrm{pH}$ in the tailings which will then flow into the Otomona river. Efforts to protect the environment around the tailings watershed of PT. Freeport Indonesia always tests water samples from mile heading 39, which is the monitoring station point after the meeting between the Aghawagon River and the tailings carrying river to find out some chemical parameters contained therein as well as monitoring results in 2016 for Ph values ranging from $7.70-8,30$ whereas based on the theoretical test results obtained values ranged from 7.89 to 8.19 thus the results of river water sample testing by PT. Freeport Indonesia compared to the theoretical calculation there is no significant difference whereas according to the applicable tailings quality standard the threshold value is 6-9 so the results of the sample test of PT. Freeport Indonesia is not in doubt and can be accepted.
\end{abstract}

Keywords: (maximum of 5 words or key phrases) 


\section{Pendahuluan}

$\mathrm{pH}$ adalah derajat keasaman digunakan untuk menyatakan tingkat keasaman atau kebasaan yang dimiliki oleh suatu larutan, nilai $\mathrm{pH}$ berkisar dari 0 hingga 14. Suatu larutan dikatakan netral apabila memiliki nilai $\mathrm{pH}=7$. Nilai pH>7 menunjukkan larutan memiliki sifat basa, sedangkan nilai $\mathrm{pH}<7$ menunjukan keasaman.

Besarnya angka pH dalam suatu perairan dapat dijadikan indikator adanya keseimbangan unsur-unsur kimia dan dapat mempengaruhi ketersediaan unsur-unsur kimia dan unsurunsur hara yang amat bermanfaat bagi kehidupan vegetasi akuatik. $\mathrm{pH}$ air juga mempunyai peranan penting bagi kehidupan ikan dan fauna lain yang hidup di perairan tersebut. Umumnya, perairan dengan tingkat $\mathrm{pH}$ yang lebih kecil dari 4,8 dan lebih besar dari 9,2 sudah dapat dianggap tercemar.

Semenjak PT Freeport Indonesia melakukan penambangan, sampai saat ini jutaan ton tailing hasil pengolahaan telah dibuang, dari 7.275 ton/hari di tahun 1973, meningkat menjadi 31.040 ton/hari di tahun 1988 dan pada saat ini menjadi 223.100 ton/hari (jatam.org).

Untuk mengetahui kemungkinan tailing hasil pengolahan bijih oleh PT Freeport Indonesia masih mengandung bahan-bahan kimia maka dilakukan uji sampel air sungai tailing pada Timika Environment Laboratorium (TEL) dengan Standar Operasional Prosedur (SOP) yang telah ditetukan.

Dalam penelitian ini hasil uji sampel air sungai tailing yang diperoleh terutama pada salah satu parameter yaitu kandungan nilai $\mathrm{pH}$ akan di bandingkan dengan perhitungan secara teori dengan tujuan untuk mengetahui tingkat keakurasian peralatan pada Timi$k a$ Environmet Laboratorium (TEL) dengan mengacu pada baku mutu tailing yang telah ditetapkan.

\section{Metode Penelitian}

Obyek dalam penelitian ini adalah menghitung besaran nilai pH pada air sungai Otomona di Mile Pos 39 setelah terakumulasinya antara air aliran sungai Otomona dengan aliran air sungai Aghawagon yang diakibatkan dari kegiatan proses pengolahan bijih terhadap tailing dengan memperhatikan jumlah nilai penggunaan kapur pada proses flotasi. Metode penelitian ini adalah meliputi:

- Pengambilan data sekunder antar lain:

Besaran nilai pH pada tailing, peta lokasi, Literature, kesampaian daerah, peta geologi, curah hujan, data produksi.

- Data primer yang diambil tentang besaran nilai potential of hydrogen $(\mathrm{pH})$ dengan menggunakan Standar Operasional Prosedur (SOP) yang telah ditentukan.

Peralatan yang diperlukan untuk mengambil dan menguji sampel air antara lain:

- Gayung sebagai alat untuk mengambil sampel dari sungai.

- Jerigen digunakan sebagai alat untuk menampung dan membawa sampel air ke laboratorium.

- Gelas ukur $1000 \mathrm{ml}$ sebagai takaran air sampel

- $\quad$ pH meter lengkap dengan elektrode digunakan sebagai alat untuk mengukur besaran nilai $\mathrm{pH}$.

- Botol digunakan sebagai penyimpanan sampel.

\section{Cara kerja pengujian sampel}

1. Kalibrasi alat $\mathrm{pH}$ meter.

2. Analisis contoh.

a. Tuang $1000 \mathrm{~mL}$ contoh air sampel ke dalam gelas ukur.

b. Celupkan elektrode $\mathrm{pH}$ meter ke dalam contoh, dan baca $\mathrm{pH}$ larutan sam- 
pai pembacaan stabil dari alat.

c. Bilas elektrode dengan air bebas mineral untuk setiap pengukuran, dan keringkan dengan kertas tissue

\section{Pabrik Pengolahan Bijih}

Pabrik pengolahan (Mill) menghasil-kan konsentrat tembaga dari bijih yang ditambang melalui pemisahan mineral berharga dari pengotornya. Langkah-langkah utamanya adalah penghancuran, penggerusan, pengapungan dan pengeri-ngan. Penghancuran dan penggerusan mengubah bongkah bijih menjadi berukuran halus.

Penghalusan ukuran butir berfungsi untuk membebaskan butiran yang mengandung tembaga dan emas, serta untuk proses pemisahan dan menyiapkan ukuran yang sesuai dengan proses selanjutnya. Bijih yang sudah halus diolah selanjutnya melalui proses flotasi, yaitu untuk mkenghasilkan konsentrat tembaga. Permukaan mineral yang bersifat hydrophobic atau aerophilic (menolak air) dipisahkan dengan yang bersifat hydrophilic atau aerophobic (menerima air). Sisa hasil pengolahan bijih disebut tailing.

\section{Penggunaan Reagen}

Salah satu syarat proses pengolahan bijih dengan teknik flotasi adalah ketika proses berlangsung umpan bijih dalam tangki flotasi harus basa dengan nilai $\mathrm{pH}$ berkisar antara 9 - 11, maka dalam hal ini sangat diperlukan kapur $(\mathrm{CaO})$ untuk mencapai dan menstabilkan nilai $\mathrm{pH}$ tersebut dan didukung oleh beberapa zat kimia yang lainnya agar proses flotasi dapat dinyatakan berhasil dan perolehan konsentrat sesuai yang diinginkan. Berikut penggunaan jenis reagen yang digunakan untuk proses flotasi pada PT. Freeport Indonesi.
Tabel 1. Jenis Reagen Yang Digunakan

\begin{tabular}{|c|c|}
\hline Reagen & Merk \\
\hline Primary Collector & Cytec S-7249 \\
\hline Secondary collector & SIBX \\
\hline Frother & F-597 (Frother) \\
\hline CaO ke Pabrik bijih & MAHAKA \\
\hline Flokulan & Magnaflog 3230 FPT \\
\hline
\end{tabular}

\section{Pos Pantau Mile Post 39}

Mile Pos 39 adalah salah satu stasiun pantau tailing yang terletak setelah pertemuan antara dua aliran Daerah Aliran Sungai (DAS) yaitu Sungai Otomona dan Sungai Aghawagon, yang mana Sungai Otomona adalah aliran airnya dimanfaatkan oleh PT. Freeport Indonesia sebagai pembawa tailing dari proses pengolahan bijih sedangkan Sungai Aghawagon merupakan sungai alami yang belum terkontaminasi oleh kegiatan usaha pertambangan, sebagai gambaran dapat dilihat pada Gambar 4.3 pada area tersebut pekerja untuk melakukan pengambilan sample tailing untuk diuji kandungannya serta untuk mengetahui TSS dan debit air sungai setiap harinya. ${ }^{8 j}$

Untuk mengetahui berapa besar nilai $\mathrm{pH}$ yang terkandung pada Sungai Otomana yaitu pertemuan antara Sungai Aghawagon dengan sungai pembuangan tailing hasil pengolahan bijih pada PT. Freeport Indonesian perlu dilakukan beberapa kajian antara lain :

- Besaran curah hujan pada daerah sekitar Daerah Aliran Sungai Aghawagon.

- Luas area tangkapan air hujan pada daerah sekitar DAS Aghawagon dan sungai aliran pembuangan tailing sisa hasil pengolahan.

- Besaran debit air dari masing-masing sungai.

- Besaran nilai pH pada sungai pembawa tailing. 
- $\quad$ Teori tentang reaksi kimia

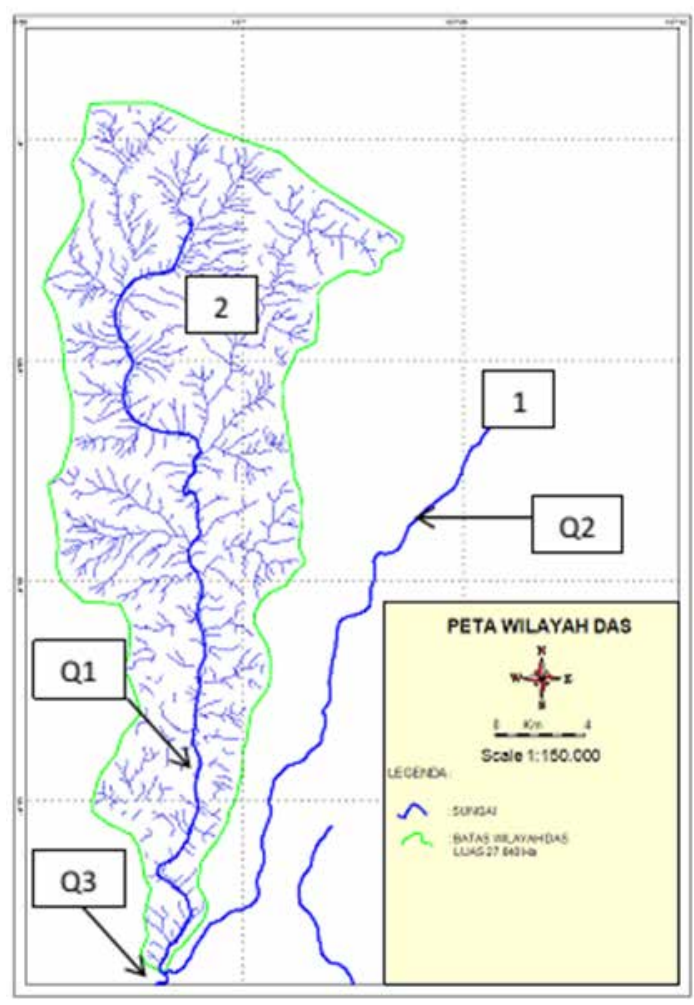

Gambar 1. Peta Wilayah DAS Penelitian

\section{Keterangan :}

1. Pabrik pengolahan bijih

2. DAS Aghawagon

$$
\begin{array}{ll}
\text { - } & \text { Q1 }=\text { Sungai Aghawagon } \\
\text { - } & \text { Q2 }=\text { Sungai Aliran Tailing } \\
\text { - } & \text { Q3 }=\text { Mile Post } 40
\end{array}
$$

Di Sungai Otamona tepatnya pada stasiun pantau mile post 39 telah dilakukan penelitian dan melakukan pengujian untuk mengetahui berapa besaran nilai $\mathrm{pH}$ yang terkandung pada sungai tersebut dan hasilnya akan dibandingkan dengan hasil uji pada TEL (Timika Environment Laboratorium) serta dengan standar baku mutu tailing yang berlaku yaitu peraturan menteri lingkungan hidup nomor 202 tahun 2004.

Sungai Aghawagon (Q1) adalah sungai alami atau sungai kualitas satu karena kualitas airnya belum terkontaminasi oleh kegiatan usaha pertambangan sehingga nilai potential of hydrogen (ph)nya masih normal yaitu sekitar 7 dengan debit air larian puncak bervarisi seperti tercantum dalam tabel 4.5 , sedang untuk sungai pembawa tailing sisa hasil pengolahan bijih dapat dihitung debitnya melalui rumus sebagai berikut:

$$
\mathrm{Q} 2=\mathrm{Q} 3-\mathrm{Q} 1
$$

Dimana:

Q2 = debit air sungai pembawa tailing dari pabrik pengolahan bijih.

$\mathrm{Q} 3$ = debit air sungai Otomona

$\mathrm{Q} 1$ = debit air sungai Aghawagon.

Adapun debit air dari ketiga sungai dalam satu tahun 2016 dari hasil perhitungan dengan menggunakan formula diatas adalah sebagai berikut:

Tabel 2. Debit Air Sungai

\begin{tabular}{|l|c|c|c|}
\hline \multicolumn{4}{|l|}{ Debit Air Sungai 2016} \\
\hline Bulan & Q1 & Q2 & Q3 \\
\hline Januari & 0.181 & 60.33 & 60.51 \\
\hline Februari & 0.208 & 128.94 & 129.15 \\
\hline Maret & 0.144 & 123.68 & 123.82 \\
\hline April & 0.124 & 109.07 & 109.19 \\
\hline Mei & 0.169 & 70.87 & 71.04 \\
\hline Juni & 0.131 & 75.73 & 75.87 \\
\hline Juli & 0.110 & 99.39 & 99.50 \\
\hline Agustus & 0.119 & 73.92 & 74.04 \\
\hline September & 0.114 & 78.93 & 79.05 \\
\hline Oktober & 0.062 & 105.80 & 105.87 \\
\hline Nopember & 0.135 & 90.76 & 90.89 \\
\hline Desember & 0.119 & 89.62 & 89.74 \\
\hline Jumlah & 1.615 & 1107.06 & 1108.677 \\
\hline
\end{tabular}

\section{Reaksi Kimia Kapur (CaO) terhadap Air $\left(\mathrm{H}_{2} \mathrm{O}\right)$}

Pada proses pengolahan bijih diperlukan nilai 
pH sebesar 10 oleh sebab itu sangat diperlukan kapur ( $\mathrm{CaO}$ ) yang berfungsi sebagai pembuih, penstabil dan menaikan nilai $\mathrm{pH}$, hal tersebut tentu akan sangat berpengaruh pada tailing terutama pada nilai $\mathrm{pH}$ (basa).

Tailing sisa hasil pengolahan bijih yang dikeluarkan oleh pabrik pengolahan bijih pada PT. Freeport Indonesia akan tercampur (diencerkan) dengan air sungai Aghawagon dan beberapa aliran air dari anak sungai disekitar daerah tersebut akan dialirkan lagi ke Sungai Otomona selanjutnya dialirkan dan diendapkan ke ModADA (Modification Ajkwa Deposite Area), berikut rumus untuk menentukan nilai $\mathrm{pH}$ dari reaksi kimia kandungan kapur $(\mathrm{CaO})$ pada tailing terhadap air sungai Aghawagon:

$$
\begin{aligned}
\mathrm{pH} \text { Q3 } & =\ldots . . . ? \\
\text { Debit Q1 } & =\ldots . . . \mathrm{m}^{3} / \mathrm{s}(\text { dengan } \mathrm{pH}=7) \\
{\left[\mathrm{OH}^{-}\right] } & =10^{-(14-7)}=10^{-7} \\
& =0,0000001 \mathrm{~mol} / \text { liter }
\end{aligned}
$$

$$
\begin{array}{ll}
\text { Debit Q2 } & =\ldots . . . \mathrm{m}^{3} / \mathrm{s}(\text { dengan } \mathrm{pH}=10) \\
\text { pOH } & =14-10=4 \mathrm{~mol} / \mathrm{liter} \\
{[\mathrm{OH}-]} & =10^{-(14-10)} \\
& =0,00001 \mathrm{~mol} / \text { liter } \\
\text { Q3 } & =\ldots . . \mathrm{m}^{3} / \text { detik }(\mathrm{pH}=\ldots . . ?) \\
{[\mathrm{OH}-]} & =\{[\mathrm{OH}-]+[\mathrm{OH}-]\} / \text { debit } \mathrm{Q} 3 \\
& =\ldots \ldots . \mathrm{mol} / \mathrm{liter} \\
\text { pOH } & =\{0,0000001+0,0001\} / \mathrm{Q} 3 \\
\text { pH Q3 } & =14-\mathrm{pog}([\mathrm{OH}-])=?
\end{array}
$$

Dari hasil perhitungan dengan menggunakan rumus tersebut maka diperoleh besaran nilai $\mathrm{pH}$ rata-rata pada Sungai Otomona (Q3) dalam setiap bulan pada tahun 2016 beserta besaran nilai $\mathrm{pH}$ yang dihitung dengan menggunakan perhitungan secara teoritis yang dibandingkan dengan nilai ambang batas yang telah ditetapkan oleh pemerintah dan Negara Indonesia yang disajikan dalam bentuk tabel sebagai berikut:

\section{Pengukuran pH Pada Sungai Tailing}

Pengukuran $\mathrm{pH}$ merupakan hal yang mutlak dilakukan di dalam pengolahan air limbah. $\mathrm{pH}$ menunjukkan konsentrasi ion hidrogen di dalam larutan. Semakin tinggi nilai pH artinya konsentrasi ion hidrogen semakin sedikit dan larutan akan bersifat basa. Sebaliknya, semakin rendah nilai $\mathrm{pH}$ maka larutan akan memiliki sifat asam karena konsentrasi ion hidrogen semakin tinggi. Secara teoritis, $\mathrm{pH}=-\log$ $\left[\mathrm{H}^{+}\right]$

Metode elektrokimia merupakan cara yang termudah dan akurat untuk mengukur $\mathrm{pH}$ air limbah, dengan metode ini pengukuran dapat langsung dilakukan di lapangan dengan alat yang disebut $\mathrm{pH}$ meter. Komponen dasar di dalam pengukuran $\mathrm{pH}$ secara elektrokimia terdiri dari elektroda $\mathrm{pH}$, elektroda pembanding, dan voltmeter (Hamilton instrument).

Pengukuran $\mathrm{pH}$ pada tailing sangat penting karena dalam pengolahan limbah yang melibatkan proses biologi, peranan $\mathrm{pH}$ sangat penting. Mikroorganisme memerlukan lingkungan dengan $\mathrm{pH}$ tertentu. Secara umum, rentang $\mathrm{pH}$ yang dapat ditolerir oleh mikroorganisme adalah pada kisaran 6.5 - 8.5. pH yang tidak sesuai atau terlalu fluktuatif dapat menurunkan kinerja proses biologi karena mikroorganisme tidak dapat melakukan metabolisme secara optimal hasilnya, proses penyisihan organik dari dalam air limbah (diwakili oleh BOD) tidak dapat berjalan dengan semestinya dan efisiensi pengolahan dapat menurun. Selain itu, $\mathrm{pH}$ yang tidak sesuai dengan persyaratan pengolahan dapat memacu tumbuhnya mikroorganisme yang tidak diinginkan. 
Tabel 3. Hasil Perhitungan Nilai pH

\begin{tabular}{|c|c|c|c|c|c|c|}
\hline \multirow[b]{2}{*}{2016} & \multicolumn{3}{|c|}{ Sungai } & \multirow{2}{*}{$\begin{array}{l}\text { Pengukuran } \\
\mathrm{pH}(\mathrm{Q} 3)\end{array}$} & \multirow{2}{*}{$\begin{array}{c}\text { Perhitungan } \\
\text { pH (Q3) }\end{array}$} & \multirow[b]{2}{*}{ NAB } \\
\hline & $\begin{array}{l}\text { Aghawagon } \\
\left(\mathrm{Q} 1-\mathrm{mm}^{3} / \mathrm{s}\right)\end{array}$ & $\begin{array}{c}\text { Tailing } \\
\left.\text { Q2 }-\mathrm{mm}^{2} / \mathrm{s}\right)\end{array}$ & $\begin{array}{c}\text { Otomona } \\
\left(Q 3-m^{3} / s\right)\end{array}$ & & & \\
\hline Januari & 0.181 & 60.33 & 60.51 & 7.94 & 8.22 & \multirow{12}{*}{$6-9$} \\
\hline Fcbruari & 0.208 & 128.94 & 129.15 & 7.75 & 7.89 & \\
\hline Maret & 0,144 & 123.68 & 123,82 & 7.72 & 7.91 & \\
\hline April & 0.124 & 109.07 & 109.19 & 7.67 & 7.96 & \\
\hline Mei & 0.169 & 70.87 & 71.04 & 7.54 & 8.15 & \\
\hline Juni & 0.131 & 75.73 & 75.87 & 7.15 & 8.12 & \\
\hline Juli & 0.110 & 99.39 & 99.30 & 8.14 & 8.00 & \\
\hline Agustus & 0.119 & 73.92 & 74.04 & 7.50 & 8.13 & \\
\hline September & 0.114 & 78.93 & 79.05 & 7.67 & 8.10 & \\
\hline Oktober & 0.062 & 105.80 & 105.87 & 7.75 & 7.98 & \\
\hline Nopember & 0.135 & 90.76 & 90.89 & 7.68 & 8.04 & \\
\hline Desember & 0.119 & 89.62 & 89.74 & 7.57 & 8.05 & \\
\hline
\end{tabular}



Gambar 2. Grafik Perbandingan Hasil Pengukuran Dengan Perhitungan

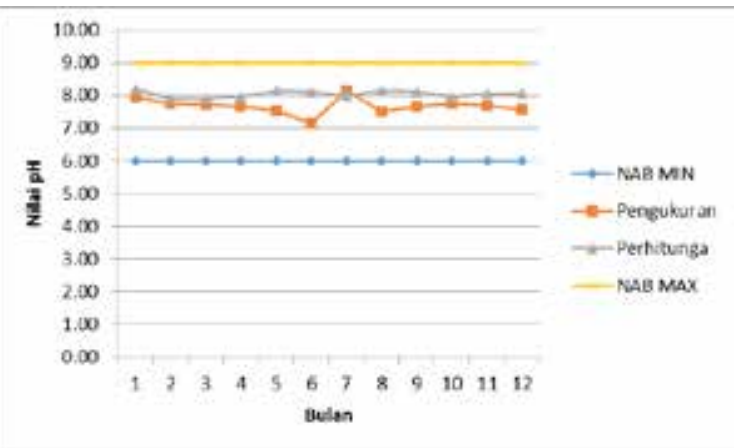

Gambar 2. Grafik Pebandingan Antara Nilai pH Pengukuran, Perhitungan dan Nilai Ambang Batas (Baku Mutu)

\section{Baku Mutu Tailing di Indonesia}

Secara teknis baku mutu tailing di Indonesia diatur dalam Keputusan Menteri Lingkungan Hidup yang terus diperbarui. Baku Mutu ter- baru tentang tailing diatur dalam KepMenLH No. 202/2004 tentang Baku Mutu Air Limbah Bagi Usaha dan atau Kegiatan Pertambangan Bijih Emas dan atau Tembaga. Dalam KepMenLH No. 202/2004 juga diatur tentang pengetatan persyaratan dan sistem pengawasan melalui kewajiban tambahan yang harus dipenuhi oleh PTFI dalam pengelolaan tailing yang dihasilkan. ${ }^{5)}$

\section{Hasil Penelitian dan Pembahasan}

Cara yang termudah untuk memenuhi Dari data penelitian di atas diperoleh data yang terdiri dari 2 (dua) kelompok data, yaitu data aktual perusahaan dan data teroritis. Data yang dimaksud adalah data nilai kandungan pH air Sungai Otomona dengan nilai rata-rata setiap bulan selama satu tahun 2016. Dimana, besaran nilai $\mathrm{pH}$ pada sungai sudah dipengaruhi oleh Sungai Aghawagon dan anak sungai lainnya yang ada disekitarnya dan memiliki nilai pH sebesar 7 serta memiliki debit air yang bervariasi karena nilai $\mathrm{pH}$ dari tailing sisa pengolahan bijih sebesar 10 sehingga diperoleh besaran nilai yang bervariasi pula.

Ketika data yang diperoleh dari perusahaan dengan data hasil perhitungan secara teoritis dilakukan uji homogenitas dengan rumus statistik menggunakan Microsoft Excel maka didapatkan hasil "Tidak Homogen" dan berdasarkan perhitungan secara statistik pula maka didapatkan Fhitung lebih kecil dari Ftabel $(0,0009<4,30)$ sehingga Ho diterima, dengan demikian nilai pH sebagaimana disampaikan oleh PT. Freeport Indonesia dapat diterima hasilnya.

Dengan demikian hasil perbandingan antara pengukuran nilai $\mathrm{pH}$ pada Sungai Otomona dan nilai $\mathrm{pH}$ hasil perhitungan dengan menggunakan Microsoft Excel menggunakan data yang berkaitan dengan Nilai Ambang Batas (NAB) baku mutu tailing sisa hasil pengolahan bijih pertambangan tembaga, perak dan emas yang telah ditentukan oleh pemerintah 
maka didapatkan bahwa tailing yang dihasilkan oleh PT. Freeport Indonesia memenuhi standar baku mutu.

\section{Kesimpulan}

Dari hasil penelitian yang dilaksanakan di PT. Freeport Indonesia maka dapat disimpulkan sebagai berikut:

1. Bedasarkan perhitungan secara teoritis didapatkan nilai $\mathrm{pH}$ air Sungai Otomona berkisar antara 7,89 - 8,19 sedangkan berdasarkan hasil pengujian sampel pada laboratorium didapatkan nilai berkisar antara 7,70 - 8,30 dengan demikian hasil pengujian sampel air sungai oleh PT. Freeport Indonesia dibandingkan dengan perhitungan secara teoritis tidak terdapat perbedaan yang signifikan maka dengan demikian hasil uji sampel tidak diragukan.

2. Semakin besar debit air Sungai Aghawagon maka pengaruhnya terhadap nilai $\mathrm{pH}$ pada Sungai Otomona semakin rendah, begitu juga sebaliknya ketika debit air Sungai Aghawagon kecil maka derajat nilai $\mathrm{pH}$ pada Sungai Otomona tinggi.

3. Pengaruh debit air Sungai Aghawagon terhadap besaran nilai pH pada air Sungai Otomona sangat kecil karena tidak mampu merubah nilai pH hingga ke nilai angka
7 (pH netral).

4. Tailing yang hasilkan dari sisa proses pengolahan bijih oleh PT. Freeport Indonesia tidak melampaui Nilai Ambang Batas (NAB) yang telah ditetapkan oleh pemerintah yaitu KepMenLH 202/2004 tentang "Baku Mutu Air Limbah Bagi Usaha dan atau Kegiatan Pertambangan Bijih Emas dan atau Tembaga".

5. Ternyata Fhitung < Ftabel sehingga Ho diterima, dengan demikian nilai $\mathrm{pH}$ sebagaimana disampaikan PT. Freeport Indonesia dapat diterima hasilnya.

\section{Saran}

Adapun saran yang dapat disampaikan terhadap PT. Freeport Indonesia mengenai penelitian ini adalah sebagai berikut:

1. PT. Freeport Indonesia agar dapat mempertahankan dalam pengelolaan tailing terutama terhadap nilai $\mathrm{pH}$ air yang terkandung di dalamnya.

2. PT. Freeport Indonesia harus mampu menjadi contoh dalam teknik pengelolaan tailing bagi perusahaan tambang lainnya dan supaya siap untuk menerima kunjungan dari perusahaan lain dalam rangka pembelajaran tentang teknik pengelolaan tailing 


\section{Daftar Pustaka}

.www.ptfi.co.id

.........KepMenLH 202/2004 tentang Baku Mutu Air Limbah Bagi Usaha dan atau Kegiatan Pertambangan Bijih Emas dan atau Tembaga.

Asdak, Chay. 1995. Hidrologi dan Pengelolaan Daerah Aliran Sungai. Gadjah Mada University Press. Yogyakarta.

Kiti, S, 2010, Kimia Itu Asik https://books.google.com/books?isbn= 9791391696 -

Mahbub. M, “Ilmu Tanah Unlam”, Penuntun Praktikum Agrohirologi

Talkurputra, M. Nad. D. 1979. Faktor-faktor yang Mempengaruhi Debit Air dan Kadar Lumpur Perairan Sungai di Jawa Barat. Program Doktor. Institut Pertanian Bogor. 